\title{
ANALYSIS OF THE AGRICULTURAL LAND MARKET TRANSACTIONS IN SELECTED REGIONS OF SLOVAKIA IN THE YEARS 2007-2016
}

\author{
Štefan BUDAY*, Ol'ga ROHÁČIKOVÁ, Lubica RUMANOVSKÁ \\ Slovak University of Agriculture in Nitra, Slovak Republic
}

\begin{abstract}
Despite the fact that the agricultural land market in Slovakia has developed in recent years, the overwhelming part of agricultural land in Slovakia is utilized in the form of rent. Only a small part is managed by the landowners themselves. It is therefore necessary to create mechanisms that would make it easier for both beginners and experienced farmers to acquire land as a basic factor of production. It is also important to create conditions enabling agricultural land to continue to serve its purposes and be acquired by persons who are competent for the management of the land and will manage it in compliance with the criteria of good agricultural and environmental practice. Research and analysis of factors affecting the land market and the rental market with agricultural land will also play an important role in these directions. During the evaluated period 2007-2016, we analyzed 244,374 land plots of agricultural land in twelve districts of the Slovak Republic (hereinafter referred also as SR). In the twelve districts of Slovakia, from 2007 to 2016, the average market price agricultural land without a distinction of size categories showed a fluctuating trend. Higher values of the average market price of agricultural land were recorded in the first years of the reviewed period. The highest value of the average market price was recorded in 2008 and amounted to $2.76 € . \mathrm{m}^{-2}$. During the monitored period, from 2007 to 2011 , the average market price had always values exceeding $1 € . \mathrm{m}^{-2}$. In the reviewed twelve districts of Slovakia during the monitored period, the sold area of agricultural land represented acreage of 100,574 ha. From this acreage, the largest share (58.41\%) scored arable land followed by permanent grassland with a share of $40.92 \%$. Orchards marked the $0.43 \%$ share of the total acreage and the smallest share (only $0.23 \%$ ) of the total sales was represented by vineyards.
\end{abstract}

Keywords: Agricultural land, land price, land plots, sale, average market price

The development of land market is directly proportional to the agro-sector performance and the profitability of individual agricultural entities. Effective use of agricultural land has a significant impact on the harmonized economic and environmental parameters of production at both national and regional level. In particular, ownership and land use relationships, but also the existing natural assumptions of the regions, play a decisive role. The further direction of the development of the land market, the rental market and the taxation of agricultural land is also important (Buday, Čičová, Grausová and Buday, 2015; Lazíková et al., 2012; Voltr et al.,2015). Besides economic performance, it is also necessary to point out that the land markets need proper institutional environment and the reduction of frictions that may hamper their performance (Holst, Eberlin and Onera 2012).

Agricultural land accounts for more than half of the area of Slovakia. Agriculture in Slovakia has a long tradition; it has always been self-sufficient in basic foodstuffs and has been able to apply to foreign markets for commodity markets. According to research realized by Vilcek and Koco, in terms of agricultural production potential, $15.3 \%$ of soils in Slovakia are very highly productive, $22.2 \%$ are highly productive, $24.0 \%$ are medium, $15.0 \%$ are low-productive and $23.5 \%$ are very low-productive agricultural soils. The resulting integrated index of agricultural soils quality in Slovakia indicates $1.0 \%$ of very high quality, $30.3 \%$ of high quality, $37.9 \%$ of medium quality, $30.5 \%$ of low quality and $0.3 \%$ of very low quality of soils (Vilček and Koco, 2018).

According to Ždárková (2002), soil is further understood as an advantageous capital thesaurus, not subject to inflation. As the world's land is fixed, the number of people on the planet is growing with increased demands on space and livelihood, and it also needs to be emphasized that, above all, high-quality farmland is and will be the desired investment. Growth in agricultural land prices in the world has been strong in recent years, influenced by non-food use of agricultural land and its decline in terms of both quantitative and qualitative aspects. According to the European Environment Agency (2003), Europe is one of the most intensively used continents in the world. The way it is used is one of the major causes of environmental change that has a significant impact on quality of life and ecosystems and on infrastructure management. However, it is important to control the extent of agricultural land and its numerous functions - food production, nature conservation, recreation and housing. Increasing land-use for urbanization is primarily at the expense of farmland. Therefore, the Common Agricultural policy gave priority to subsidies primarily linked to the agricultural land itself 
(Single Farm Payment), to enhance market orientation. The change from mainly production related subsidies to land subsidy, raised further still the need for reliable and comparable prices on agricultural land (European Commission, 2013). The level of land prices depends on a number of national (laws), regional (climate, proximity to networks) and localised factors (soil quality, slope, drainage etc.) as well as the market forces of supply and demand (including influence of foreign ownership rules). As such, it is interesting to note developments in prices for regions over time. According to the European Commission (2018), the land prices vary considerably between and within the Member States, and Slovakia belongs to the countries with large differences within region in arable land prices.

The analysis of structure of agricultural land prices and agricultural land transactions was published by various authors (Plantinga, Lubowski and Stavins, 2002; Buday and Vilček, 2013; Buday et al., 2016; Rumanovská, 2014; Vilhelm et al., 2013). According to them there are efforts to understand potential threats to agriculture posed by land development and to identify policies to prevent or discourage what may be considered socially undesirable land-use changes. Land prices reflect not only land use, but also its potential use. In a competitive market, the price of land will equal the discounted sum of expected net returns (or utility) obtained by allocating the land to its most profitable use. That use surely may change over time. If, for example, agricultural production is currently the most profitable use, but development for some other purpose is expected to yield even greater net returns in the future, then the current land price should reflect both uses in a simple additive form: the sum of the discounted stream of near-term rents from agriculture plus the discounted stream of expected rents from development beginning at some time in the future. Based on the mentioned research it is important to focus on the developments of agricultural land market transactions. According to Baran, Bandlerová, Takáč and Straňák (2012), elimination of the distortive effects that affect the price of land and the unification of tax levy could ultimately bring the necessary impetus to the launch of this market segment. The creation of mechanisms that would facilitate the beginners and also experienced farmers to get the basic means of production - land - is referred as important.

The paper focuses on the analysis of transactions on the agricultural land market in selected districts of Slovakia. The analysis was carried out using data from the annual monitoring of land market from the Bonita Bank of Data (BBD) of the Research Institute of Agriculture and Food Economics. Data from the BBD are mainly used in the decision-making sphere when creating concepts and directions of the Common agricultural policy in the Slovak Republic conditions, providing regular information for the needs of the Statistical Office of the SR, Eurostat and the monitoring report for the OECD.

\section{Material and methods}

The basic data for the analysis of the paper was the data on the agricultural land market, in selected regions of Slovakia, obtained from the cadastre of real estate transactions on land in twelve selected districts of the SR from 2007 to 2016. The selected regions were Banská Bystrica (BB), Dunajská Streda (DS), Košice-okolie (KE), Liptovský Mikuláš (LM), Michalovce (MI), Nitra (NR), Prešov (PO), Rimavská Sobota (RS), Svidník (SK), Topolčany (TO), Trnava (TT), Žilina (ZA). The most important monitored variables were: district code, the code of the cadastral area, parcel number, land price in $€ . \mathrm{m}^{-2}$, the plot, plot location code, and date of land transfer. For the evaluation, the data from selected sale and purchase contracts related to agricultural land transfers reported for a deposit according to cadastral territories in selected districts for the period of the relevant (evaluated) calendar year were used.

The collected data were examined in terms of location. Land located in local municipalities was excluded for evaluation purposes. Further, the data was reviewed for the type of land, and the type of garden plot was excluded from the assessment. The data were supplemented with the names of the regions. Additionally, size categories and size ranges were added to the dataset.

Outputs in MS Excel were evaluated both by immediate analysis of specific values, which is more suitable for files smaller and medium sized as well as methods of statistical analysis.

In order to compare the sold areas within the cadastral territories/districts with the total area of the respective cadastral area / district, the existing databases on agricultural land area, type of land and data from Informational sheets from the Ministry of Agriculture and Rural Development of SR were used.

Data transformation and processing was performed using the UNIX operating system, the INFORMIX database system, and a structured SQL query language. In addition to the analytical tools of Excel, statistical software SPSS (Statistical Package for Social Sciences) and NCC software (Number Cruncher Statistical Software) were used for statistical evaluation.

\section{Results and discussion}

\section{Intensity of sales and purchases transactions of agricultural land in the twelve districts of Slovakia from 2007 to 2016}

In the twelve selected districts of Slovakia for the period from 2007 to 2016, we analyzed 244,374 plots with agricultural land. From this number, $66.58 \%$ were plots with arable land. Another major share on the total plots was land with permanent grassland, namely $32.75 \%$. The share of sold vineyards represented only $0.54 \%$ and the share of sold orchards was even smaller, only $0.13 \%$.

The largest amout of sold agricultural land was in the district of Liptovský Mikuláš and accounted for $18.00 \%$ of the total land sold. Next in line was Žilina, where the number of sold plots was $14.16 \%$. These were followed by the districts of Rimavská Sobota (13.54\%) and Košice-okolie with a sales share of $12.37 \%$. The least amount of plots with agricultural land was sold in the Svidník district (1.28\%). Most plots of arable land were sold in the Žilina region, representing 13.98\%, followed by Liptovský Mikuláš (13.18\%) and 


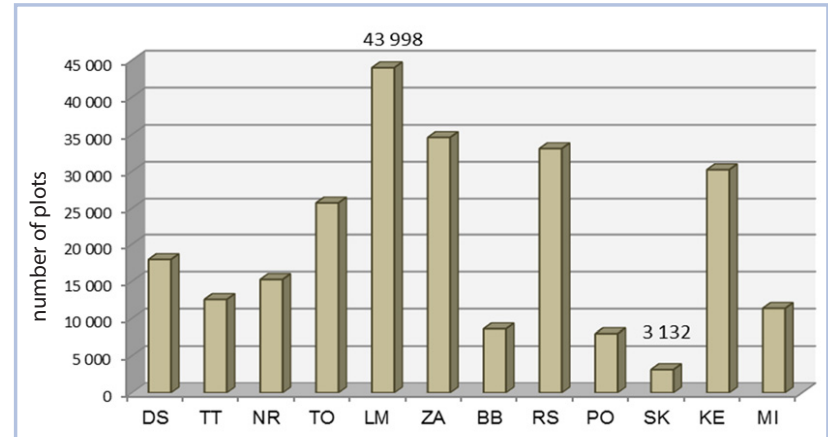

Figure 1 Number of sold land plots in the twelve districts of the SR in the years 2007 to 2016

Source: VUEPP, author's calculations, 2018

Košice-okolie with $13.15 \%$. Next in order were the districts Rimavská Sobota (12.60\%) and Topolčany (12.50\%). The districts with the least number of sold plots of arable land included Banská Bystrica (2.39\%) and Svidník (1.49\%). The sale of land under permanent grassland in terms of their number was the largest within the Liptovský Mikuláš district (28.09\%), followed by the districts of Rimavská Sobota (15.15\%) and Žilina (14.78\%). The lowest numbers of plots under permanent grassland were sold in Trnava (1.66\%) and the district Svidník, only $0.88 \%$. Within the selection of twelve districts, vineyards were sold in seven districts. Most vineyard plots were sold in the districts of Nitra (42.70\%) and Rimavská Sobota (31.63\%). The smallest share of vineyards in the total number of vineyards sold was in Košice-okolie district $(0.38 \%)$. The districts with the largest share of orchard sales were Liptovský Mikuláš (25.39\%) and Košiceokolie (23.51\%). On the other hand, the low proportion of land sales with orchards was in the Banská Bystrica district $(0.63 \%)$ and the same in the Michalovce district $(0.63 \%)$. The lowest share of orchard sales was in the Svidník district and amounted to $0.31 \%$.
The sold acreage of agricultural land in the twelve districts of Slovakia for the period 2007-2016 represented the total amount of $1005739673 \mathrm{~m}^{2}$ (about 100,574 ha), as shown in table 1 . Of this total area, arable land accounted for the largest share $(58.41 \%)$, followed by permanent grassland, whose share amounted to $40.92 \%$. Orchards share of total sales amounted to $0.43 \%$ and the smallest share (only $0.23 \%$ ) of total sales were represented vineyards.

The evaluation of the amount of agricultural land sales from the regional point of view showed that the Košiceokolie district $(25.61 \%)$ was the district with the highest selling rate, followed by Rimavská Sobota (24.04\%) and the third in row was the Topolčany district, where the sold area accounted for $16.48 \%$ of the total sales of agricultural land. To the districts with the lowest acreage of sold agricultural land belongs Banská Bystrica (1.60\%), Žilina (1.59\%) and Svidník (1.54\%).

The largest acreage of arable land was sold in the Topol'čany district (23.67\%), followed by Košice-okolie (19.58\%) and Rimavská Sobota, where arable land sales amounted to $18.72 \%$. A small acreage of arable land was sold in the districts of Žilina (1.47\%), Svidník (1.38\%) and the smallest share of arable land was sold in Banská Bystrica $(0.84 \%)$. Regarding the sales of permanent grassland, there dominated the district Košice-okolie, where the sold area represented $34.62 \%$ of the total area of sold permanent grasslands, followed by the district of Rimavská Sobota with a share of $31.46 \%$ sold permanent grassland. The smallest area of permanent grasslands in the period under review was sold in the districts of Nitra (1.62\%), Trnava (1.17\%) and Dunajská Streda (0.77\%). The largest area of vineyards from the evaluated districts was sold in the Nitra district (40.91\%). Next in line was the district Rimavská Sobota (29.91\%). The smallest share of vineyard sales was in the Košice-okolie district $(0.59 \%)$. The district Topol'čany dominated by the sold area of the orchards, where the sold area represented $62.70 \%$. Next in line was the district

Table 1 Acreage of agricultural land sold in the period from 2007 to 2016 in the twelve districts of the SR by type of land

\begin{tabular}{|l||c|c|c|c|c|}
\hline \multirow{2}{*}{ District } & \multicolumn{5}{|c|}{ Acreage $\left.\mathbf{( m}^{2}\right)$} \\
\cline { 2 - 6 } & agricultural land & arable land & vineyards & orchards & permanent grassland \\
\hline \hline Dunajská Streda & 34492792 & 31046959 & 119889 & 143286 & 3182658 \\
\hline Trnava & 60468376 & 55386917 & 268567 & 14991 & 4797902 \\
\hline Nitra & 58996929 & 51205010 & 958729 & 173240 & 6659949 \\
\hline Topolčany & 165704244 & 139028611 & 227937 & 2724939 & 23722757 \\
\hline Liptovský Mikuláśs & 42951763 & 20650613 & - & 311601 & 21989549 \\
\hline Žilina & 15974115 & 8660255 & - & 22647 & 7291213 \\
\hline Banská Bystrica & 16098536 & 4921521 & - & 755 & 11176260 \\
\hline Rimavská Sobota & 241781288 & 109980621 & 700840 & 862919 & 130236908 \\
\hline Prešov & 31751899 & 17469255 & - & 27840 & 14254804 \\
\hline Svidník & 15504401 & 8108639 & - & 1860 & 7393901 \\
\hline Košice-okolie & 257575569 & 115021583 & 13872 & 59753 & 142480361 \\
\hline Michalovce & 64439762 & 25993127 & 53595 & 2000 & 38391040 \\
\hline Total & 1005739673 & 587473112 & 2343430 & 4345831 & 411577300 \\
\hline
\end{tabular}

Source: VUEPP, author's calculations, 2018 
Rimavská Sobota (19.86\%). The districts with the smallest share of the sold area of orchards were Trnava $(0.34 \%)$ and Michalovce (0.05\%).

\section{The average market price of agricultural land in twelve districts of Slovakia for the period 2007 to 2016}

The average market price of agricultural land for a period of ten years (2007-2016) in the selected set of twelve districts of Slovakia had a value of $0.84 € . \mathrm{m}^{-2}$ (Table 2). According to the type of land, the highest average market price was monitored by vineyards. Their average market price was $2.84 € . \mathrm{m}^{-2}$ for the whole monitored period, followed by arable land, with the average market price of $1.05 € . \mathrm{m}^{-2}$. The next, according to the average market price, were orchards with an average market price of $1.00 € . \mathrm{m}^{-2}$. The lowest average market price was recorded by permanent grasslands, which amounted to $0.52 € . \mathrm{m}^{-2}$.

The evaluation by district showed that for the period from 2007 to 2016, the highest average market price of agricultural land was in the Žilina district and its value was $4.13 € . \mathrm{m}^{-2}$. Next in line was the district Prešov with the value of $2.72 € . \mathrm{m}^{-2}$ and the third was the Banská Bystrica district, where the value of the average market price of agricultural land was $2.70 € . \mathrm{m}^{-2}$. In the next group of districts, the average market price of agricultural land was significantly lower than the above mentioned prices. Three districts were located in the production areas of Dunajská Streda $\left(1.65 € . \mathrm{m}^{-2}\right)$, Trnava $\left(1.63 € . \mathrm{m}^{-2}\right)$ and Nitra $\left(1.44 € . \mathrm{m}^{-2}\right)$. Even slightly lower price was recorded within the districts - up to $1.25 € . \mathrm{m}^{-2}$. In the other monitored districts, the average market price of land was below $1 € . \mathrm{m}^{-2}$. The lowest average market price of agricultural land was in the Michalovce districts $\left(0.25 € . \mathrm{m}^{-2}\right)$ and Svidník $\left(0.21 € . \mathrm{m}^{-2}\right)$.

The highest value of the average market price of arable land over the monitored period of ten years was recorded in the Žilina district $\left(5.23 € . \mathrm{m}^{-2}\right)$, followed by the Prešov district with the value of $4.03 € . \mathrm{m}^{-2}$ and the third in row was the Banská Bystrica district $\left(2.66 € . \mathrm{m}^{-2}\right)$. The ranking of other districts according to the amount of the average market price of arable land was similar to the market price of agricultural land, followed by the districts of Dunajská Streda $\left(1.74 € . \mathrm{m}^{-2}\right)$, Trnava $\left(1.73 € . \mathrm{m}^{-2}\right)$ and Nitra $\left(1.44 € . \mathrm{m}^{-2}\right)$. To the districts with the lowest average market price of arable land belong the districts of Rimavská Sobota $\left(0.31 € . \mathrm{m}^{-2}\right)$, Svidník $\left(0.28 € . \mathrm{m}^{-2}\right)$ and Topol'čany $\left(0.27 € . \mathrm{m}^{-2}\right)$.

The average market price of permanent grassland was highest in the district of Žilina, where it was $2.82 € . \mathrm{m}^{-2}$. The second highest price was marked in the district of Banská Bystrica where the average market price of permanent grasslands was $2.72 € . \mathrm{m}^{-2}$ followed by the district of Prešov where the average market price amounted to $1.04 € . \mathrm{m}^{-2}$. In other districts, the average market price of permanent grassland was below $1 € . \mathrm{m}^{-2}$. The lowest average market price of permanent grassland was recorded in the Svidník district $\left(0.14 € . \mathrm{m}^{-2}\right)$ and in the Michalovce district $\left(0.07 € . \mathrm{m}^{-2}\right)$.

The highest average market price of vineyards was recorded in the district of Nitra, where the selling price was $5.53 € . \mathrm{m}^{-2}$. Then, the district Dunajská Streda followed with an average market price of vineyards amounting to $4.51 € . \mathrm{m}^{-2}$. The lowest average market price of vineyards was in the districts of Rimavská Sobota $\left(0.19 € . \mathrm{m}^{-2}\right)$ and Košiceokolie $\left(0.15 € . \mathrm{m}^{-2}\right)$.

The highest average market price of orchards was in the Prešov district ( $35.11 € . \mathrm{m}^{-2}$ ), followed by the Košice-okolie district $\left(22.73 € . \mathrm{m}^{-2}\right)$ and the relatively high average market price of the orchards was also recorded in the district of Trnava (19.86 €. $\mathrm{m}^{-2}$ ). The lowest average market price of orchards was in Rimavská Sobota $\left(0.17 € . \mathrm{m}^{-2}\right)$, Topol'čany $\left(0.15 € . \mathrm{m}^{-2}\right)$ and Michalovce $\left(0.03 € . \mathrm{m}^{-2}\right)$.

Table 2 The average market price of land in twelve selected districts of Slovakia by type of land for the period from 2007 to 2016

\begin{tabular}{|l||c|c|c|c|c|}
\hline \multirow{2}{*}{ District } & \multicolumn{5}{c|}{ Price $\left(€ \mathbf{m}^{-\mathbf{2}}\right)$} \\
\cline { 2 - 6 } & agricultural land & arable land & vineyards & orchards & permanent grassland \\
\hline \hline Dunajská Streda & 1.65 & 1.74 & 4.51 & 2.79 & 0.63 \\
\hline Trnava & 1.63 & 1.73 & 1.40 & 19.86 & 0.53 \\
\hline Nitra & 1.44 & 1.44 & 5.53 & 1.05 & 0.81 \\
\hline Topolčany & 0.33 & 0.27 & 0.90 & 0.15 & 0.70 \\
\hline Liptovský Mikuláš & 1.25 & 1.79 & - & 1.71 & 0.73 \\
\hline Žilina & 4.13 & 5.23 & - & 2.37 & 2.82 \\
\hline Banská Bystrica & 2.70 & 2.66 & - & 6.00 & 2.72 \\
\hline Rimavská Sobota & 0.29 & 0.31 & 0.19 & 0.17 & 0.28 \\
\hline Prešov & 2.72 & 4.03 & - & 35.11 & 1.04 \\
\hline Svidník & 0.21 & 0.28 & - & 2.44 & 0.14 \\
\hline Košice-okolie & 0.81 & 1.23 & 0.15 & 22.73 & 0.47 \\
\hline Michalovce & 0.25 & 0.53 & 1.98 & 0.03 & 0.07 \\
\hline Total & 0.84 & 1.05 & 2.84 & 1.00 & 0.52 \\
\hline
\end{tabular}




\section{Year-to-year comparison of the development of the land market in the twelve districts of Slovakia from 2007 to 2016}

Development of the number and acreage of sold land plots The number of sold land plots and the sold acreage of agricultural land in the selected twelve districts of Slovakia showed a fluctuating trend from 2007 to 2016 as shown in Figure 2. Lower number of plots and smaller acreage of land were recorded in the first half of the evaluated period (2007-2011). Since 2012, there has been an increase in the number of sold plots and sold acreage of land. Boths values culminated in 2014. During the first eight years, the development of land plots was more or less identical to the development of land acreage sales. In 2015, there was a partial decrease in the number of sold land plots compared to the previous year, but the decrease in sold acreage of land was more significant. The same development was recorded in 2016. This fact shows that in the most recent years, land plots with a small or smaller acreage dominated by the land sales.

\section{Evaluation of the development of the average market price of agricultural land in the monitored twelve districts of Slovakia from 2007 to 2016}

Within the selected twelve districts of Slovakia in the period from 2007 to 2016, the average market price of agricultural land showed a fluctuating trend (Figure 3). Higher values of the average market price of agricultural land were recorded in the first monitored period. The highest value of the average market price was recorded in 2008 and amounted to $2.76 € . \mathrm{m}^{-2}$. During the monitored period from 2007 to 2011, the average market price exceeded $1 € . \mathrm{m}^{-2}$. In 2012, for the first time since 2007, the average market price of agricultural land fell below $1 € . \mathrm{m}^{-2}$, up to $0.67 € . \mathrm{m}^{-2}$. In 2013, the average market price partially increased, but next year decreased again and the lowest value was recorded during this period, amounting to $0.41 € \cdot \mathrm{m}^{-2}$. Since 2014 , the average

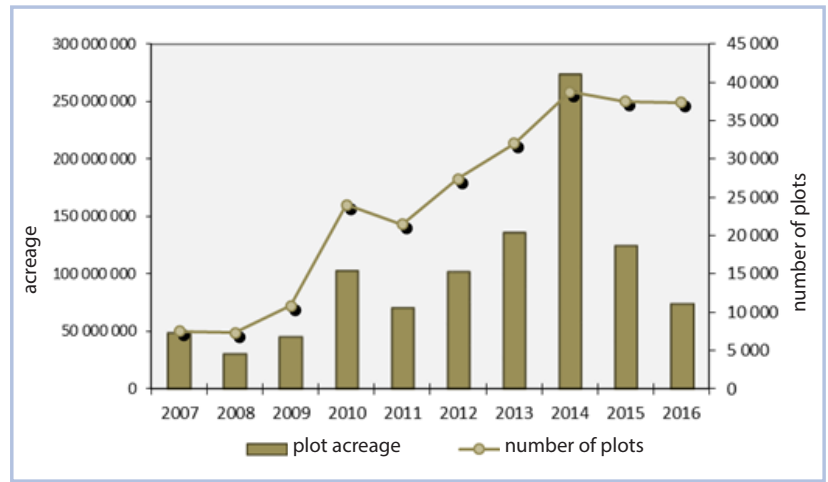

Figure 2 Development of the number of land plots and the acreage of sold agricultural land in the twelve districts of Slovakia between 2007 and 2016 Source: VUEPP, author's calculations, 2018

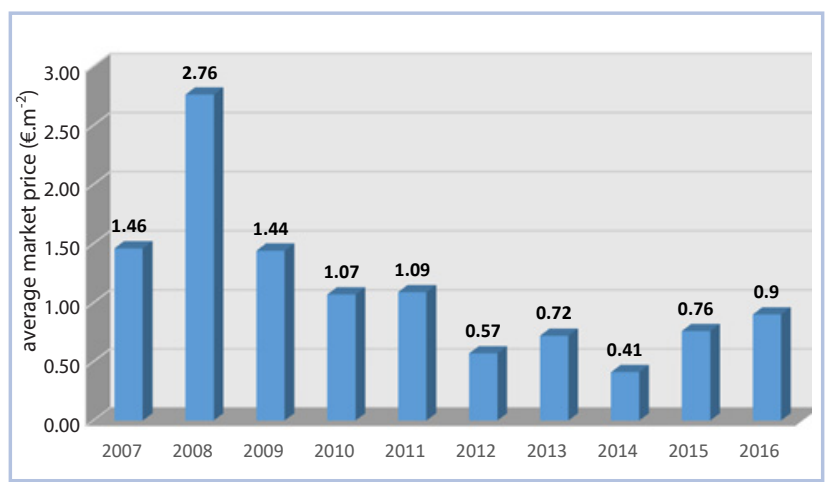

Figure 3 Development of the average market price of agricultural land without distinction of the size categories for the twelve districts of Slovakia from the year 2007 to 2016

Source: VUEPP, author's calculations, 2018

Table 3 Development of the average market price of agricultural land in the twelve districts of Slovakia from the year 2007 to 2016

\begin{tabular}{|l|c|c|c|c|c|c|c|c|c|c|c|}
\hline District & $\mathbf{2 0 0 7}$ & $\mathbf{2 0 0 8}$ & $\mathbf{2 0 0 9}$ & $\mathbf{2 0 1 0}$ & $\mathbf{2 0 1 1}$ & $\mathbf{2 0 1 2}$ & $\mathbf{2 0 1 3}$ & $\mathbf{2 0 1 4}$ & $\mathbf{2 0 1 5}$ & $\mathbf{2 0 1 6}$ & $\mathbf{2 0 0 7 - 2 0 1 6}$ \\
\hline \hline DS & 1.64 & 3.09 & 1.83 & 2.62 & 2.34 & 1.81 & 0.75 & 1.34 & 1.09 & 0.94 & 1.65 \\
\hline TT & 2.94 & 6.40 & 2.91 & 2.07 & 0.96 & 0.67 & 0.39 & 0.65 & 1.01 & 2.78 & 1.63 \\
\hline NR & 2.31 & 4.89 & 1.93 & 2.30 & 1.36 & 1.56 & 0.38 & 0.61 & 0.62 & 2.13 & 1.44 \\
\hline TO & 0.33 & 1.02 & 0.68 & 0.18 & 0.68 & 0.30 & 0.18 & 0.18 & 0.45 & 0.55 & 0.33 \\
\hline LM & 4.19 & 4.83 & 1.51 & 0.90 & 0.70 & 0.77 & 0.69 & 0.65 & 1.46 & 2.17 & 1.25 \\
\hline ZA & 4.88 & 3.22 & 2.75 & 4.73 & 4.37 & 3.47 & 4.68 & 3.39 & 5.70 & 9.80 & 4.13 \\
\hline BB & 5.06 & 5.25 & 2.77 & 5.28 & 7.07 & 8.09 & 2.31 & 2.37 & 7.07 & 1.63 & 2.70 \\
\hline RS & 0.11 & 0.16 & 0.15 & 0.45 & 0.23 & 0.27 & 0.74 & 0.17 & 0.16 & 0.23 & 0.29 \\
\hline PO & 0.76 & 4.25 & 1.69 & 1.91 & 6.41 & 6.34 & 3.11 & 1.84 & 5.05 & 4.13 & 2.72 \\
\hline SK & 0.08 & 0.50 & 0.11 & 0.04 & 0.27 & 1.38 & 0.01 & 0.14 & 0.73 & 0.20 & 0.21 \\
\hline KE & 2.14 & 3.49 & 1.13 & 1.13 & 1.04 & 0.80 & 0.93 & 0.36 & 0.84 & 2.56 & 0.81 \\
\hline MI & 1.97 & 0.98 & 1.50 & 0.15 & 1.04 & 0.19 & 0.05 & 0.01 & 0.24 & 0.22 & 0.25 \\
\hline Total & 1.46 & 2.76 & 1.44 & 1.07 & 1.09 & 0.67 & 0.72 & 0.41 & 0.76 & 0.90 & 0.84 \\
\hline
\end{tabular}

Source: VUEPP, author's calculations, 2018 


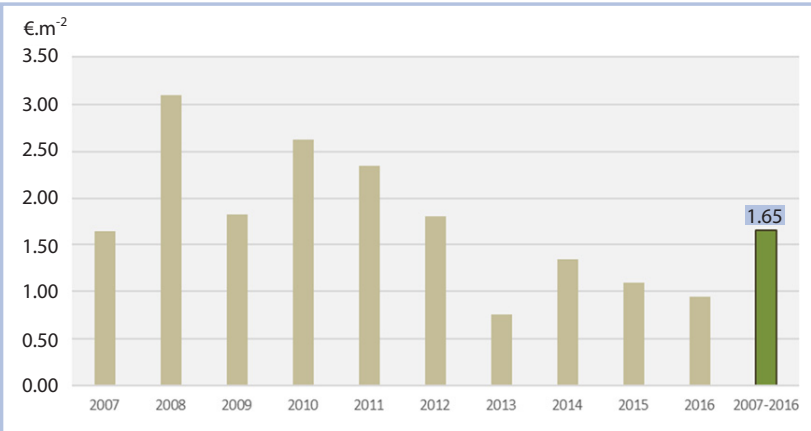

Figure 4 Development of the average market price of agricultural land in the district of Dunajská Streda from 2007 to 2016

Source: VUEPP, author's calculations, 2018

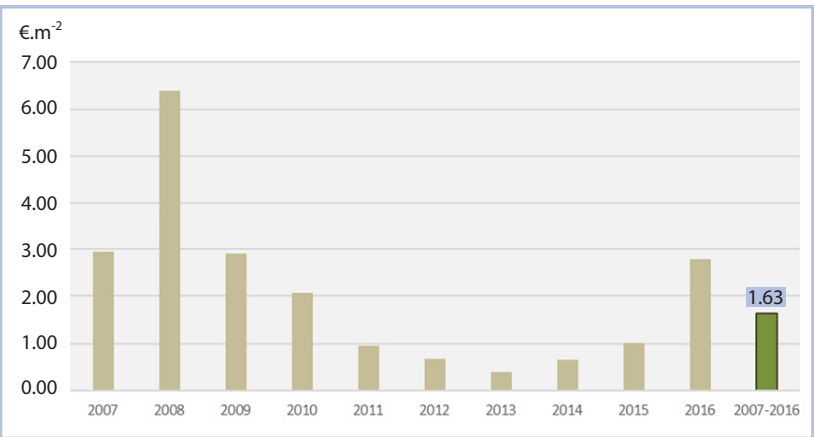

Figure 5 Development of the average market price of agricultural land in the Trnava district from 2007 to 2016

Source: VUEPP, author's calculations, 2018

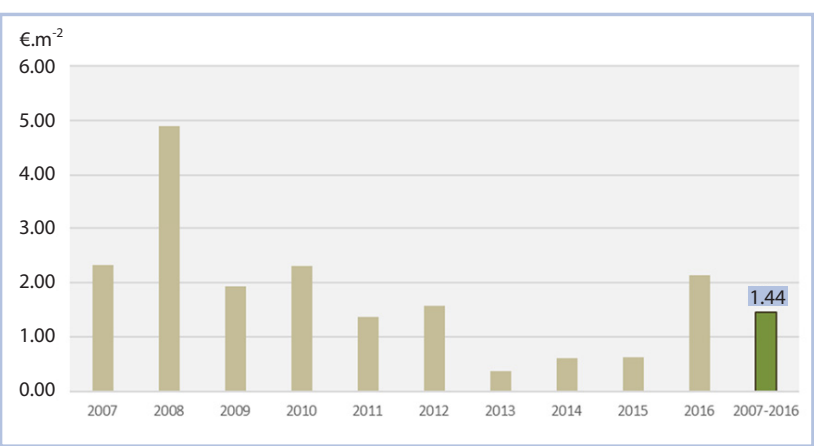

Figure 6 Development of the average market price of agricultural land in the Nitra district from 2007 to 2016

Source: VUEPP, author's calculations, 2018

market price has risen again, but its value has not reached $1 € . \mathrm{m}^{-2}$. The difference between the lowest and highest average market prices during the period under review was $2.35 € . \mathrm{m}^{-2}$. In the last evaluated year, the average market price of agricultural land rose by $0.14 € . \mathrm{m}^{-2}$ compared to the previous year.

Development of the average market price of agricultural land between 2007 and 2016 in the different districts of Slovakia was significantly different and in most districts had a fluctuating course (Table 3 ). In the half of the monitored districts, the maximum value of the average market price of land during the evaluated period was recorded in 2008.
In contrast, the lowest average market price in five of the twelve districts was reported in 2013.

The district of Dunajská Streda was one of the districts that had the highest average market price of agricultural land $\left(3.09 € . \mathrm{m}^{-2}\right.$ ) in 2008 , as shown in Figure 4. After a temporary reduction in 2009, the relatively high price for agricultural land (more than $2 € . \mathrm{m}^{-2}$ ) was maintained in 2010 and 2011. Once again, after the reduction in 2012, the price fell in the next year (2013) to the lowest value during the monitored period, amounting to $0.75 € . \mathrm{m}^{-2}$. In 2014, there was an increase in the average market price, to $1.34 € . \mathrm{m}^{-2}$, but from this year on, the average market price of land in the district has declined. In the last evaluated year, the average market price of agricultural land was $0.94 € . \mathrm{m}^{-2}$. Although there was a decrease and an increase in the average price during the period under review, there were no significant differences between the prices in the individual years. The difference between the highest and the lowest average market price in the reference period was $2.34 € . \mathrm{m}^{-2}$. The average market price in this district for the entire monitored period was $1.65 € . \mathrm{m}^{-2}$.

The development of the average market price of agricultural land in the Trnava district was also fluctuating (Figure 5). Higher values of the average market prices were recorded in the first evaluation period. The highest average market price was (as in the Dunajská Streda district) found in 2008 and its value was $6.40 € \mathrm{~m}^{-2}$. This value was significantly higher compared to the values in 2013 and 2014 (where the values were the lowest), but also compared to the relatively high value of the average market price in 2007 and 2009. The difference between the highest and lowest average market price was $6.01 € . \mathrm{m}^{-2}$. Since 2008, the average market price gradually declined until 2013 to the lowest level $\left(0.39 € . \mathrm{m}^{-2}\right)$. Then there followed a gradual increase in the value of average market prices and in the last reporting year, it amounted to $2.78 € . \mathrm{m}^{-2}$. The average market price of agricultural land for the whole monitored period was $1.63 € . \mathrm{m}^{-2}$.

In the district Nitra there was also monitored a fluctuating trend in the development of the average market price of agricultural land (Figure 6). Also, in this district, the highest average market price $\left(4.89 € . \mathrm{m}^{-2}\right)$ was recorded in 2008. In the following period, the average market price decreased and increased sharply. The lowest value of the average market price was reported in 2013 , similarly as in the previous districts, when its value was only $0.38 € . \mathrm{m}^{-2}$. In the following years, the average market price gradually increased to $2.13 € . \mathrm{m}^{-2}$ in 2016 . Between the highest and lowest average market price there was in this district also considerable difference, which amounted to $4.51 € . \mathrm{m}^{-2}$. The average market price for the whole period had the value of $1.44 € . m^{-2}$.

In the Topolčany district there were no significant differences in the average market prices of agricultural land recorded during the monitored period 2007-2016 (Figure 7). Although throughout the period the price fluctuated, the difference between the highest and the lowest recorded average market prices was only $0.84 € . \mathrm{m}^{-2}$ and it was one of the lowest differences within the selected twelve districts. The highest average market price, as in all previous districts, was recorded in 2008, when it was $1.02 € . \mathrm{m}^{-2}$. During the 


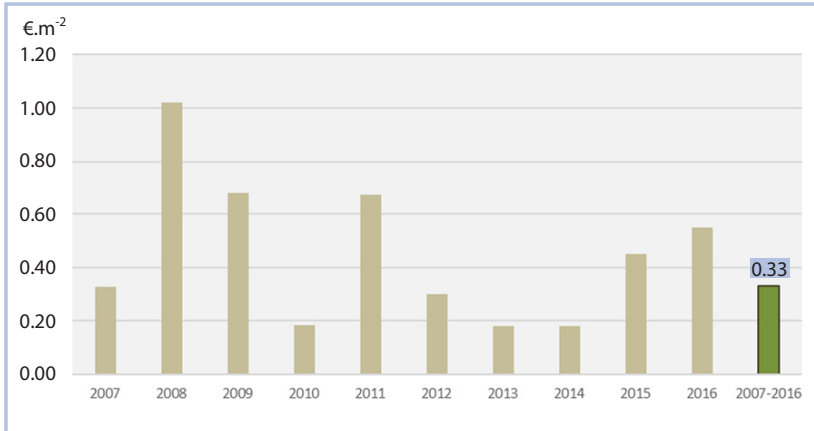

Figure 7 Development of the average market price of agricultural land in the Topol'čany district from 2007 to 2016

Source: VUEPP, author's calculations, 2018

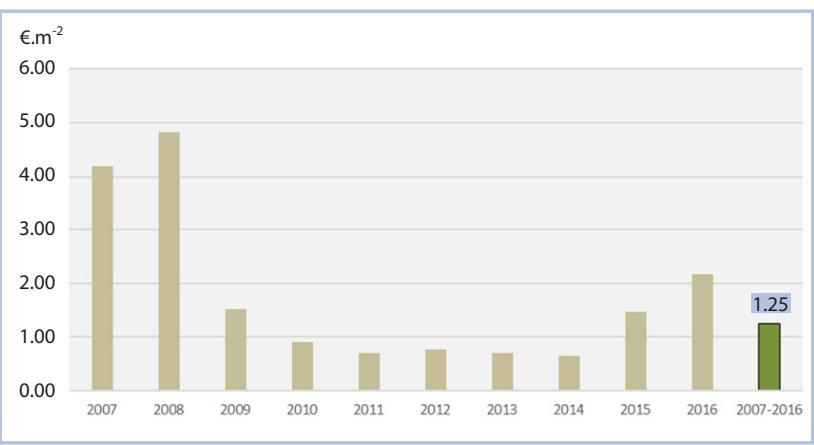

Figure 8 Development of the average market price of agricultural land in the Liptovský Mikuláš district from 2007 to 2016

Source: VUEPP, author's calculations, 2018

following years, the average market price had a fluctuating trend. The lowest average market price $\left(0.18 € . \mathrm{m}^{-2}\right)$ was recorded in three years, namely, in 2010, 2013, and 2014. In the last two years, the average market price of agricultural land increased and in 2016 it had the value of $0.55 € . \mathrm{m}^{-2}$. For the period 2007-2016, the average market price of agricultural land was $0.33 € . \mathrm{m}^{-2}$.

Liptovský Mikuláš had the highest values of the average market prices in the first two years of the evaluated period (Figure 8). Also this district recorded in 2008 the highest average market price. Its value at that time was $4.83 € . \mathrm{m}^{-2}$. Until the year 2011, average market prices of agricultural land declined gradually. In the period from 2012 to 2014, the average market price had a fairly balanced pattern. In 2014 , it recorded its minimum value of $0.65 € . \mathrm{m}^{-2}$. In the last two monitored years, the average market price recorded an increase, but it did not reach the value of the first two monitored years. Its value in 2016 was $2.17 € . \mathrm{m}^{-2}$. In this district, there were also large differences between the average market prices in individual years. The difference between the highest and lowest average market price was $4.18 € . \mathrm{m}^{-2}$. The value of the average market price of agricultural land for the whole monitored period was $1.25 € . \mathrm{m}^{-2}$.

In the Žilina district (unlike the previous districts), the highest average market price was recorded in 2016 (Figure 9). In this district, relatively high values of the average market price were recorded throughout the whole monitored period. However, the extremely high value of

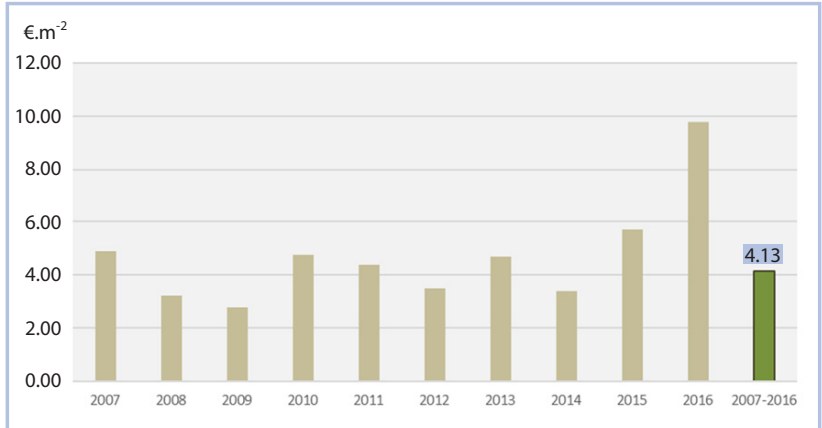

Figure 9 Development of the average market price of agricultural land in the Žilina district from 2007 to 2016

Source: VUEPP, author's calculations, 2018

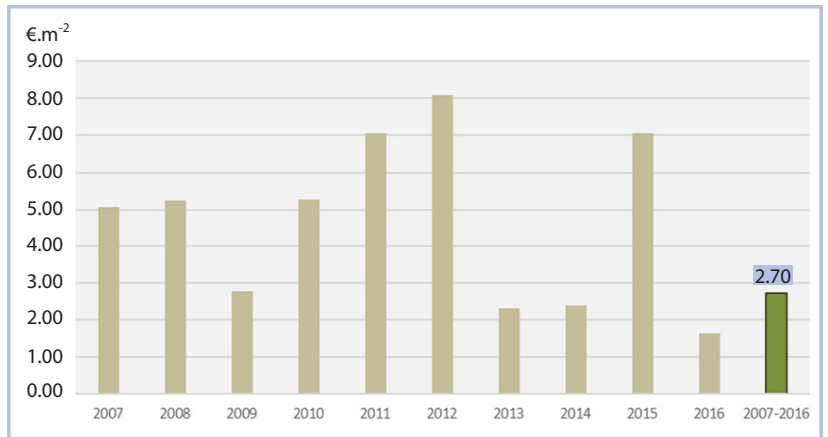

Figure 10 Development of the average market price of agricultural land in the Banská Bystrica district from 2007 to 2016

Source: VUEPP, author's calculations, 2018

the average market price was found in the last evaluated year and reached $9.80 € . \mathrm{m}^{-2}$. This increase was due to the high land prices near urban areas assuming their future recreational status. The development of the average market price of agricultural land during the years 2007 to 2016 was very fluctuating. The average market price of agricultural land from the first reference year in the following two years decreased to the minimum value $\left(2.75 € \mathrm{~m}^{-2}\right)$ in 2009. After fluctuating development of land price, it increased significantly in 2015 to $5.70 € . \mathrm{m}^{-2}$. The difference between the highest and lowest average market price was $7.05 € . \mathrm{m}^{-2}$, the highest value of the difference in price of all twelve districts. The average market price of agricultural land in the assessment period had the value of $4.13 € . \mathrm{m}^{-2}$.

Also, the district of Banská Bystrica was one of the districts with considerably high average market price during the monitored period 2007 to 2016, as shown in Figure 10. The average market price of agricultural land, which in the first years had the value of $5 € . \mathrm{m}^{-2}$, decreased to $2.77 € . \mathrm{m}^{-2}$ in 2009. Since then, it has increased up to the maximum value of $8.09 € . \mathrm{m}^{-2}$ in the monitored year 2012. Over the next two years, its value declined significantly to the value of over $2 € . \mathrm{m}^{-2}$, but in 2015 , an increase was monitored up to $7.07 € . \mathrm{m}^{-2}$. In the last year, during the monitored period, there was a significant decrease in the average market price of agricultural land to the lowest value for the whole reference period, which was $1.63 € . \mathrm{m}^{-2}$. We can note that even in this district the development of the average market price had significant fluctuations and also recorded one of 


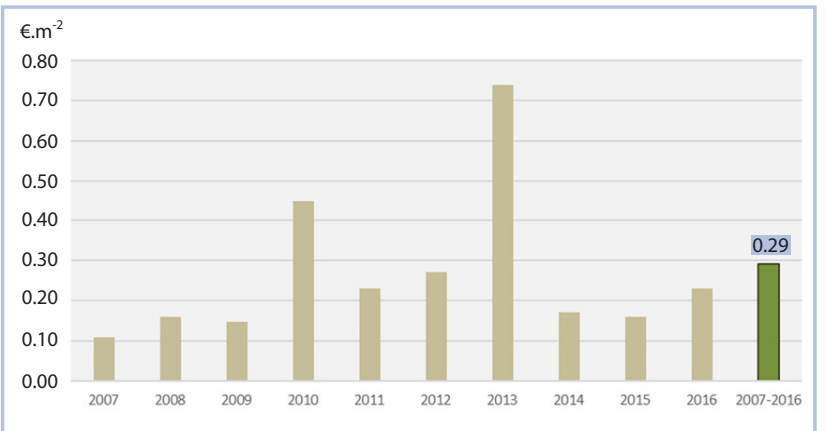

Figure 11 Development of the average market price of agricultural land in the Rimavská Sobota district from 2007 to 2016

Source: VUEPP, author's calculations, 2018

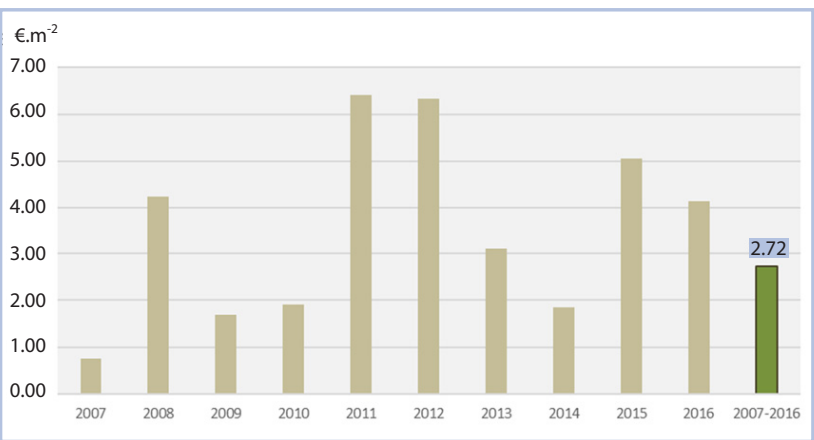

Figure 12 Development of the average market price of agricultural land in the Prešov district from 2007 to 2016

Source: VUEPP, author's calculations, 2018

the biggest differences between the highest and the lowest average market price, which was $6.46 € . \mathrm{m}^{-2}$. The average market price of agricultural land for the whole monitored period had the value $2.70 € . \mathrm{m}^{-2}$.

The district of Rimavská Sobota belongs to the districts with the lowest average market price of agricultural land (Figure 11) within the evaluated period and had the value of $0.29 € . \mathrm{m}^{-2}$. The lowest average market price was recorded at the beginning of the reference period and amounted to only $0.11 € . \mathrm{m}^{-2}$. During the whole period, the increase and decrease of the average market price varied, but they were not very significant. The difference between the highest and lowest average market prices in the monitored period was only $0.63 € . \mathrm{m}^{-2}$ and was the lowest one within the rated districts. One of the larger increases in the average market price of agricultural land was recorded in 2010, when the average market price was $0.45 € . \mathrm{m}^{-2}$. The largest increase in the average market price of agricultural land in the Rimavská Sobota district was in 2013, when the average market price was $0.74 € . \mathrm{m}^{-2}$. In the last monitored year, the average market price was $0.23 € . \mathrm{m}^{-2}$, as in one of the previous years (2011).

The fluctuations in the average market price during the period 2007-2016 were also recorded in the Prešov district (Figure 12). The average market price of agricultural land for the whole monitored period was $2.72 € . \mathrm{m}^{-2}$. Closest to this figure was the average market price in 2013, when it was $3.11 € . \mathrm{m}^{-2}$. Four years during the period under review, the

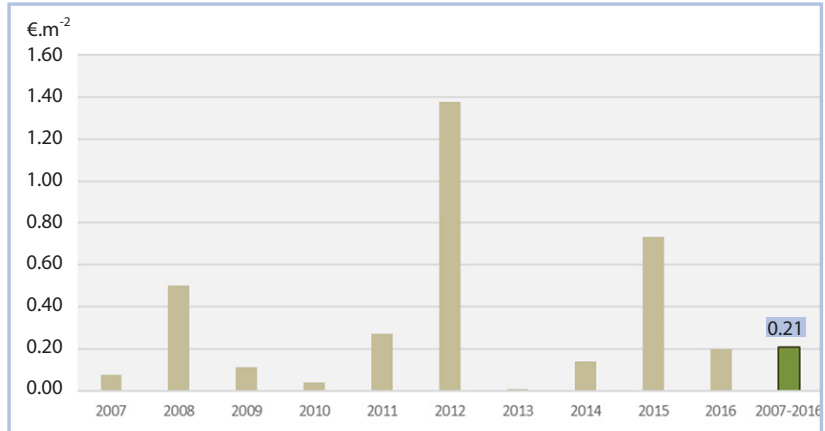

Figure 13 Development of the average market price of agricultural land in the Svidník district from 2007 to 2016

Source: VUEPP, author's calculations, 2018

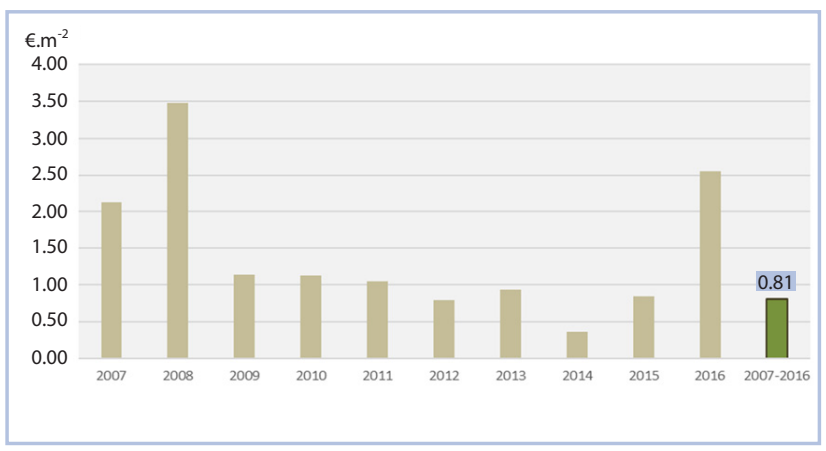

Figure 14 Development of the average market price of agricultural land in the Košice-okolie district from 2007 to 2016

Source: VUEPP, author's calculations, 2018

average market price was less than $2 € . \mathrm{m}^{-2}$. The lowest value $\left(0.76 € . \mathrm{m}^{-2}\right)$ was recorded in the first evaluation year. In the five years within the period 2007 and 2016, the average market price in the Prešov district was quite high. Twice it exceeded the value of $4 € . \mathrm{m}^{-2}$, once of $5 € . \mathrm{m}^{-2}$ and twice of $6 € . \mathrm{m}^{-2}$. Overall, during the ten monitored years, the average market price had the highest value in 2011 and amounted to $6.41 € . \mathrm{m}^{-2}$. The difference between the highest and lowest values of the average market price was significant and amounted to $5.66 € . \mathrm{m}^{-2}$.

The district Svidník belongs to the districts where the difference between the highest and lowest average market price during the reporting period was very high and amounted to $1.37 € . \mathrm{m}^{-2}$ (Figure 13). Although, as in most districts, the average market price displayed fluctuations during the period under review, they were not extreme. More significant fluctuation in the average market price occurred in the half of the monitored period, when in 2012, the average market price rose from $0.27 € . \mathrm{m}^{-2}$ and in the year 2011 to the highest value for the whole period of 1.38. €. $\mathrm{m}^{-2}$. Even more significant was the fluctuation when the highest average market price in 2012 decreased to the lowest value (0.01 €. $\mathrm{m}^{-2}$ ) within the monitored period. In this district, the lowest average market prices are reported during the reference period. The average market price of agricultural land for the whole period was $0.21 € . \mathrm{m}^{-2}$.

In the district Košice-okolie the development of the average market price during the whole monitored period 


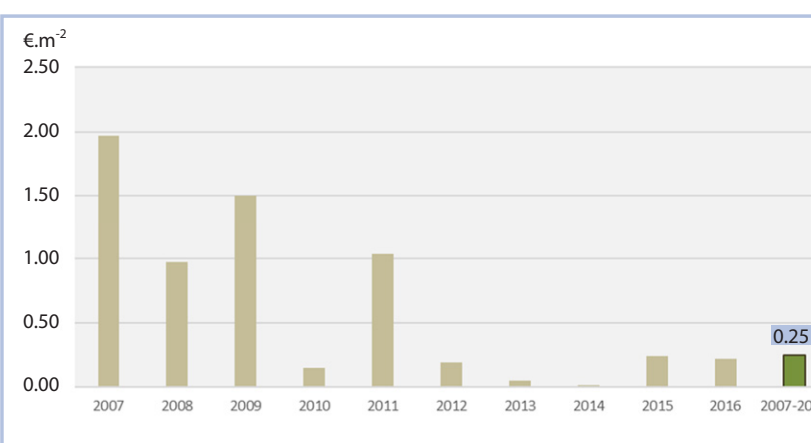

Figure 15 Development of the average market price of agricultural land in the Michalovce district from 2007 to 2016

Source: VUEPP, author's calculations, 2018

2007-2016 was quite balanced (Figure 14). The highest values of the average market prices were recorded in the first monitored period. In 2008, the average market price reached the value of $3.49 € . \mathrm{m}^{-2}$ and this was the highest value during the whole monitored period. During the period from 2009 to 2015 , the market prices were stable. The lowest average market price was in the year 2014 and had the value of $0.36 € . \mathrm{m}^{-2}$. The difference between the highest and lowest average market prices in the monitored period was $3.13 € . \mathrm{m}^{-2}$. In the last evaluated year, after the longterm equilibrium of the average market price, it increased significantly to $2.56 € . \mathrm{m}^{-2}$. The average market price of agricultural land in the district Košice-okolie was $0.81 € . \mathrm{m}^{-2}$ throughout the monitored period.

The Michalovce district belongs to districts with a relatively low average market price during the reference period (Figure 15). Even in this district, fluctuations in the average market price occurred during the period under review. The district of Michalovce is the only one where the highest average market price was recorded in the first monitored year 2007 and amounted to $1.97 € . \mathrm{m}^{-2}$. After declines and increases in the average market price in the first half of the reviewed period, the amount of the average market price has stabilized since 2012 . Also, in the second half of the monitored period there was a slight fluctuation, namely the decrease of the average market price in 2014 to the lowest value during the monitored period, which amounted to $0.01 € . \mathrm{m}^{-2}$. The difference between the highest and lowest average market price in this region amounted to $1.96 € . \mathrm{m}^{-2}$ and belongs to less significant within the sample of the twelve districts. The value of the average market price of agricultural land for the period from 2007 to 2016 was $0.25 € . \mathrm{m}^{-2}$.

\section{Conclusion}

During the evaluated period from 2007 to 2016, we have analyzed 244374 plots with agricultural land in the twelve districts of Slovakia. From this number of plots, the ones with arable land represented $66.58 \%$ and plots with permanent grassland had the share of $32.75 \%$. The share of sold vineyards represented only $0.54 \%$ and the share of sold orchards was even smaller, only $0.13 \%$.

Based on the regional division by districts, the largest number of land plots with agricultural land was sold in the Liptovský Mikuláš district and represented $18.00 \%$ of the total sold plots. On the second place there was the district of Žilina, where the share of sold plots was $14.16 \%$. Then, there followed the districts of Rimavská Sobota (13.54\%) and Košice-okolie with a sales share of $12.37 \%$. The lowest number of plots with agricultural land was sold in the Svidník district (1.28\%).

In the reviewed twelve districts of Slovakia during the period 2007-2016, the sold area of agricultural land represented an acreage of 1,005,739,673 m2 (about $100,574 \mathrm{ha})$. From this acreage, arable land created the largest share $(58.41 \%)$, followed by permanent grassland with a share of $40.92 \%$. Orchards had the $0.43 \%$ share of the total acreage and the smallest share (only $0.23 \%$ ) of the total sales was represented by vineyards.

The evaluation of sales of agricultural land from a regional point of view showed that the Košice-okolie district (25.61\%) was the district with the highest selling rate, followed by Rimavská Sobota (24.04\%) and the Topol'čany district, where the area sold accounted for $16.48 \%$ of the total sales of agricultural land. To the districts with the smallest sold area of agricultural land belong the districts of Banská Bystrica (1.60\%), Žilina (1.59\%) and Svidník (1.54\%).

In the selected set of twelve districts of Slovakia for the period 2007-2016, the average market price of agricultural land was $0.84 € \cdot \mathrm{m}^{-2}$. According to the type of land, the highest average market price was observed by the vineyard in the amount of $2.84 € . \mathrm{m}^{-2}$, followed by arable land with an average market price of $1.05 € . \mathrm{m}^{-2}$. The next, according to the average market price, were orchards with an average market price of $1.00 € . \mathrm{m}^{-2}$. The lowest average market price was reported by permanent grassland in the amout of $0.52 € . \mathrm{m}^{-2}$ over the reporting period.

The evaluation by districts showed that for the period 2007-2016 the highest average market price of agricultural land was in the Žilina district and its value was $4.13 € . \mathrm{m}^{-2}$, followed by the Prešov district, with the value of the average market price of agricultural land of $2.72 € . \mathrm{m}^{-2}$ and the third district in the order was Banská Bystrica, where the average market price of agricultural land was $2.70 € . \mathrm{m}^{-2}$. The lowest average market price of agricultural land was in the districts of Michalovce $\left(0.25 € . \mathrm{m}^{-2}\right)$ and Svidník $\left(0.21 € . \mathrm{m}^{-2}\right)$.

The number of sold plots and the sold acreage of agricultural land within the analyzed sample of the twelve districts of Slovakia showed a fluctuating trend in 2007-2016. Lower numbers of plots as well as smaller acreage were recorded in the first half of the evaluated period (2007-2011). Since 2012, there has been recorded an increase in the number of sold plots and sold acreage. Both were culminating in 2014.

In the twelve districts of Slovakia, in the period 2007-2016, the average market price of plots with agricultural land without a distinction of size categories showed a fluctuating trend. Higher values of average market prices of agricultural land were recorded in the first years under the reviewed period. The highest value of the average market price was recorded in 2008 and amounted to $2.76 € . \mathrm{m}^{-2}$. During the monitored period 2007-2011, the average market price had the value exceeding more than 1 $€ . \mathrm{m}^{-2}$. The year 2012 was the first when the average market price of agricultural land fell below $1 € . \mathrm{m}^{-2}$ to $0.67 € . \mathrm{m}^{-2}$. The average market price increased in 2013, but in the following 
year, the price declined again and recorded the lowest value during the reference period, falling to $0.41 € \cdot \mathrm{m}^{-2}$. Since 2014 , the average market price has increased again but its value has not reached $1 € . \mathrm{m}^{-2}$.

\section{Acknowledgment}

This paper was supported by the Grant Agency FESRD projects no. 7/2017 The impact of CAP supportive mechanism on the market with agricultural land in Slovakia.

\section{References}

BARAN, T. - BANDLEROVÁ, A. - TAKÁČ, I. - STRAŇÁK, P. 2012. Nelahká situácia na trhu s pôdou. In Naše pole, vol. 8, 2012, pp. 14-15. ISSN 1335-2466-XVI.

BUDAY, Š. et al. 2016. Rozvoj trhu s pôdou vo vztahu k novej spoločnej pol'nohospodárskej politike EÚ. Štúdia č. 194/2016. Bratislava: NPPC-VÚEPP, 2016. 132 pp, 59 tabuliek v texte, 49 grafov $v$ texte. ISBN 978-80-8058-607-2.

BUDAY, Š. - ČIČOVÁ, T. - GRAUSOVÁ, G. - BUDAY, M. 2015. Analýza transakcií na trhu $S$ pol'nohospodárskou pôdou $v$ roku 2015. In Ekonomika pol'nohospodárstva, vol. 16, 2016, no. 4, pp. 21-34. [Retrieved 2018-1-25]. Retrieved from: https://issuu.com/vuepp/ docs/ep_1_2014

BUDAY, Š. - VILČEK, J. 2013. Clasification and Evaluation of Agricultural Land in Slovakia. Brno : Mendelova univerzita, 2013, 130 p. ISBN 978-80-7375-789-2.

EUROPEAN COMMISSION. 2013. The CAP after 2020. [Retrieved 2018-09-10 ]. Retrieved from: https://ec.europa.eu/eurostat/ documents/2995521/8756523/5-21032018-AP-EN.pdf/ b1d0ffd3-f75b-40cc-b53f-f22f68d541pdf

EUROPEAN COMMISSION. 2018. Land prices vary considerably between and within Member States. [Retrieved 2018$10-10$ ]. Retrieved from: https://ec.europa.eu/eurostat/ documents/2995521/8756523/5-21032018-AP-EN.pdf/ b1d0ffd3-f75b-40cc-b53f-f22f68d541pdf

EUROPEAN ENVIRONMENTAL AGENCY. 2003. Land use. [Retrieved 2018-08-31 ]. Retrieved from: https://www.eea.europa.eu/cs/ themes/landuse
VAN HOLST, F. - EBERLIN, R. - ONERA, L. 2012. Land markets in Europe. [Retrieved 2018-05-30 ]. Retrieved from: file:///C:/Users/ user/Downloads/zfv_2014_3_van-Holst_Eberlin_Onega-Lopez.pdf LAZÍKOVÁ, J. - TAKÁČ, I. - NOVÁK, P. - RUMANOVSKÁ, L. ĎURKOVIČOVÁ, J. 2012. Legal and economic issues of the agricultural land rent in Slovakia (Land rent in Slovakia) In Ekonomika pol'nohospodárstva, vol. 12, 2012, no. 3, pp. 5-17. ISSN 1336-6336.

MAKOVIČKA, Z. 2013. Nákup pôdy v krajinách V-4. In Pol'nohospodársky týždenník, vol. 7, 2013, no. 23, p.18. ISSN 1337-456X.

PLANTINGA, A. - LUBOWSKI, R. - STAVINS, R. 2002. The Effects of Potential Land Development on Agricultural Land Prices. [Retrieved 2017-07-15 ]. Retrieved from: https://ageconsearch.umn.edu/ bitstream/10852/1/dp020011.pdf

SLOVAK REPUBLIC. Act No. 140/2014 Col. on Acquiring the ownership of agricultural land, as amended.

RUMANOVSKÁ, L.. 2014. Evaluation of the impact of agricultural land lease relations in agricultural subjects in Slovakia. In Scientific papers, Management, economic, engineering in agriculture and rural development, vol. 14, 2014, no. 1, pp. 315-321. ISSN 2284-7995. VILČEK, J. - KOCO, Š. 2018. Integrated index of agricultural soil quality in Slovakia. In Journal of maps, vol. 14, 2018, no. 2, pp. 6876. ISSN 1744-5647.

VILHELM, V. et al. 2013. Vývoj trhu se zemědělskou půdou a identifikace faktorů ovlivňujících vývoj cen zemědělské půdy v podmínkách ČR. Zpráva o výsledcích tematického úkolu, 1. výstup, Praha : ÚZEl, 2013, 87 pp.

VOLTR, V. et al. 2015. Podmínky převodů zemědělské půdy a jejich role v podpoře trhu s půdou v ČR a vybraných sousedních zemích. Výskumný projekt, Praha : UZEl, 2015.

ŽĎÁRKOVÁ, V. 2012. Agricultural systems. [Retrieved 2017-0504 ]. Retrieved from: http://www.kubenka.org/PEF/1_rocnik/ Zemedelske-systemy/Rajonizace.pdf 